\title{
Endothelial-like cells in chronic thromboembolic pulmonary hypertension: crosstalk with myofibroblast-like cells
}

Seiichiro Sakao ${ }^{1 *}$, Hiroyuki Hao ${ }^{2}$, Nobuhiro Tanabe ${ }^{1}$, Yasunori Kasahara ${ }^{1}$, Katsushi Kurosu ${ }^{1}$ and Koichiro Tatsumi ${ }^{1}$

\begin{abstract}
Background: Chronic thromboembolic pulmonary hypertension (CTEPH) is characterized by intravascular thrombus formation in the pulmonary arteries.

Recently, it has been shown that a myofibroblast cell phenotype was predominant within endarterectomized tissues from CTEPH patients. Indeed, our recent study demonstrated the existence of not only myofibroblast-like cells (MFLCs), but also endothelial-like cells (ELCS). Under in vitro conditions, a few transitional cells (co-expressing both endothelial- and SM-cell markers) were observed in the ELC population. We hypothesized that MFLCs in the microenvironment created by the unresolved clot may promote the endothelial-mesenchymal transition and/or induce endothelial cell (EC) dysfunction.

Methods: We isolated cells from these tissues and identified them as MFLCs and ELCs. In order to test whether the MFLCs provide the microenvironment which causes EC alterations, ECs were incubated in serum-free medium conditioned by MFLCs, or were grown in co-culture with the MFLCs.

Results: Our experiments demonstrated that MFLCs promoted the commercially available ECs to transit to other mesenchymal phenotypes and/or induced EC dysfunction through inactivation of autophagy, disruption of the mitochondrial reticulum, alteration of the SOD-2 localization, and decreased ROS production. Indeed, ELCs included a few transitional cells, lost the ability to form autophagosomes, and had defective mitochondrial structure/ function. Moreover, rapamycin reversed the phenotypic alterations and the gene expression changes in ECs cocultured with MFLCs, thus suggesting that this agent had beneficial therapeutic effects on ECS in CTEPH tissues.
\end{abstract}

Conclusions: It is possible that the microenvironment created by the stabilized clot stimulates MFLCs to induce EC alterations.

Keywords: neointima, myofibroblast, endothelial cells, CTEPH.

\section{Background}

It is generally known that chronic thromboembolic pulmonary hypertension (CTEPH) is one of the leading causes of severe pulmonary hypertension. CTEPH is characterized by intravascular thrombus formation and fibrous stenosis or complete obliteration of the pulmonary arteries [1]. The consequence is increased pulmonary vascular resistance, resulting in pulmonary hypertension and progressive right heart failure.

\footnotetext{
* Correspondence: sakaos@faculty.chiba-u.jp

'Department of Respirology (B2), Graduate School of Medicine, Chiba

University, 1-8-1 Inohana, Chuo-ku, Chiba 260-8670, Japan Full list of author information is available at the end of the article
}

Pulmonary endarterectomy (PEA) is the current mainstream of therapy for CTEPH [2]. Moreover, recent studies have provided evidence suggesting that, although CTEPH is believed to result from acute pulmonary embolism [3,4], small-vessel disease appears and worsens later in the course of disease [5]. Histopathologic studies of microvascular changes in CTEPH have shown indistinguishable vascular lesions from those seen in idiopathic pulmonary arterial hypertension (IPAH) and Eisenmenger's syndrome [6-8]. Especially in vitro and ex vivo experiments, pulmonary artery endothelial cell (EC) in the group of pulmonary hypertensive diseases are suggested to exhibit an unusual hyperproliferative
C Biomed Central 
potential with decreased susceptibility to apoptosis $[9,10]$, indicating that dysfunctional EC may contribute to the progression of the diseases.

Recently, Firth et al showed that multipotent mesenchymal progenitor cells are present in endarterectomized tissues from patients with CTEPH, and that a myofibroblast cell phenotype was predominant within these tissues, contributing extensively to the vascular lesion/clot [11]. Indeed, we have also demonstrated the existence of not only myofibroblast-like cells (MFLCs), but also endothelial-like cells (ELCs) in these tissues [12]. Under in vitro conditions, morphological alterations were more easily detected in the ELCs. Smooth muscle (SM)-like cells (defined by their expression of $\alpha$ SM-actin (SMA)) and a few transitional cells (co-expressing both endothelial- (von Willebrand factor) and SM( $\alpha$-SMA) cell markers) were consistently observed by immunohistochemical staining (preliminary data).

In vitro experiments conducted to assess the contribution of ECs to the development of pulmonary arterial hypertension (PAH) have demonstrated that the shift to a transdifferentiated phenotype could be attributed to selection of distinct cell subpopulations (i.e., stem-like cells). These findings also suggest that the endothelialmesenchymal transition (EnMT) might be an important contributor to pathophysiological vascular remodeling in the complex vascular lesions of PAH [13], because, although bone marrow-derived cells could participate in arterial neointimal formation after mechanical injury, they did not contribute substantially to pulmonary arterial remodeling in an experimental PAH model [14].

Autophagy is a catabolic process involving the degradation of intracellular material that is evolutionarily conserved between all eukaryotes. During autophagy, cytoplasmic components are engulfed by double-membrane-bound structures (autophagosomes) and delivered to lysosomes/vacuoles for degradation [15]. Recent studies indicate that autophagy plays an important role in many different pathological conditions. Indeed, both activation and inactivation of autophagy may impact cancer cell growth. If autophagy cannot be activated, protein synthesis predominates over protein degradation, and tumor growth is stimulated. In contrast, autophagy may be activated in more advanced stages of cancer to guarantee the survival of cells in minimallyvascularized tumors [16].

The interactions between ECs and smooth muscle cells (SMCs), which exist in close contact via a functional syncytium, are involved in the process of new vessel formation that occurs during development, as part of wound repair, and during the reproductive cycle [17-19]. We hypothesized that MFLCs stimulated by the microenvironment created by the unresolved clot may promote ECs to transit to other mesenchymal phenotypes and/or induce EC dysfunction, contributing to the vascular lesion, i.e., not only proximal vasculature, but also microvascular. In the experiments considered here, we isolated cells from endarterectomized tissue from patients with CTEPH and identified them as MFLCs and ELCs. In order to show the hypothesis, human pulmonary microvascular ECs were incubated in a serum-free medium conditioned by MFLCs, or ECs were co-cultured with MFLCs. The aim of this study was to examine whether MFLCs in the microenvironment created by the unresolved clot can, in principle, affect EC disorder through the EnMT and autophagy.

\section{Methods}

\section{Cell lines and reagents}

The PEA tissues of patients with CTEPH were obtained following PEA performed by Dr. Masahisa Masuda at the Chiba Medical Center, Japan. Control pulmonary arteries were obtained following lung resection for peripheral cancer by Dr. Ichiro Yoshino at the Chiba University Hospital, Japan. Written informed consent was acquired before surgery from all patients from whom tissue samples were obtained. The study was approved by the Research Ethics Committee of Chiba University School of Medicine, and all subjects gave their informed consent in writing. Although not clinically accurate, the PEA tissues were defined as mentioned below. PEA samples obtained from the region directly surrounding the fibrotic clot are referred to as "proximal" vascular tissue and those obtained from areas after the fibrotic clot region are referred to as the "distal" vascular tissue [11]. The tissues were cultured and various explant outgrowth cells were dissociated as described previously [12]. Myofibroblast-like cells (MFLCs) and endotheliallike cells (ELCs) were isolated and identified from endarterectomized tissue from patients with CTEPH and pulmonary arterial fibroblast-like cells from control pulmonary arteries. PEA samples obtained from a total of six patients undergoing PEA were examined in this study.

Human pulmonary microvascular ECs were obtained from Lonza Inc (Allendale, NJ, USA). The following antibodies were used during our present studies: mouse anti- $\alpha$-SMA (1:1000, Sigma, St. Louis, MO, USA), mouse anti-vimentin (1:200, DAKO, Carpinteria, CA, USA), mouse anti-human desmin (1:100, DAKO, Carpinteria, CA, USA), anti-mouse IgG Ab conjugated with Rhodamine dye (1:500, Molecular Probes, Eugene, OR, USA), rabbit anti-von Willebrand factor (Factor VIII) (1:1000, DAKO, Carpinteria, CA, USA), anti-rabbit IgG conjugated with Alexa-488 fluorescent dye (1:500, Molecular Probes, Eugene, OR, USA), and rabbit anti-CD31 (1:1000, DAKO, Carpinteria, CA, USA). Rapamycin was purchased from Merck (Frankfurter, Germany). 


\section{Immunofluorescence staining}

The cells were fixed in a 1:1 mixture of methanol and acetone for 2 minutes followed by blocking with normal goat serum for 30 minutes as described previously [13]. The cells were incubated with primary antibodies (anti$\alpha$-smooth muscle actin (SMA), anti-von Willebrand factor, anti-vimentin and anti-desmin) for 1 hour at room temperature, and then with secondary antibodies (antimouse IgG conjugated with Alexa-594 fluorescent dye and anti-rabbit IgG conjugated with Alexa-488 fluorescent dye) for 1 hour at room temperature. Stained cells were embedded in VectaShield mounting medium with DAPI (Vector Laboratories, Burlingame, CA, USA) and were examined with a NIKON Eclipse 80 i microscope (Nikon, Tokyo, Japan) using the VB-7210 imaging system (Keyence, Tokyo, Japan). Positive cells were counted in 3 different fields at a magnification of $\times 200$ using a fluorescence microscope.

\section{Double immunohistochemical staining}

Endarterectomized samples were embedded in optimal cutting temperature (OCT) compound (Sakura Tissue Tek), frozen, and cut into $10-\mu \mathrm{m}$ sections with a cryostat. For basic characterization, standard hematoxylin and eosin (H \& E) staining was performed. The CD31 antibody was used to stain endarterectomized tissue, together with $\alpha$ SMA to stain transitional cells. $\alpha$ SMA staining (blue) was developed with alkaline phosphataseconjugated secondary antibody, and then CD31 staining (brown) was developed with peroxidase-conjugated secondary antibody. Transitional cells were confirmed by aSMA positively stained cytosol that also had concomitant positive cytoplasmic staining in CD31 positive cells.

\section{ELISA (Enzyme-Linked ImmunoSorbent Assay)}

TGF- $\beta_{1}$ were measured by sandwich ELISA techniques by ELISA Tech (Aurora, CO, USA) utilizing reagents from R\&D systems (Minneapolis, MN, USA). The samples were read in a spectrophotometer at $405 \mathrm{~nm}$. Antibodies and tracer were bought from Cayman Chemicals (Ann Arbor, Mi, USA).

\section{Human pulmonary microvascular ECs in the conditioned medium}

At passage 2 MFLCs or pulmonary arterial fibroblastlike cells were seeded at a density of $1.5 \times 10^{4}$ cells $/ \mathrm{cm}^{2}$ and were subcultured when they were to $90 \%$ confluences (4-8 days). They were washed 3 times using phosphate-buffered saline (PBS) and were incubated with serum-free medium for 48 hours. HPMVEC were seeded in $6 \mathrm{~cm}$ dishes at $1 \times 10^{5}$ density and cultured in EGM supplemented with $5 \%$ fetal bovine serum. At 70 to $80 \%$ confluence they were washed 3 times with PBS, incubated in the conditioned medium for 48 hours and incubated in EGM again for 48 hours. After the incubation periods, they were assessed microscopically, further characterized by immunohistochemical staining and harvested to extract RNA for quantitative RT-PCR and to extract protein for ELISA.

\section{Co-culture of human pulmonary microvascular ECs and MFLCs}

Co-culture of human pulmonary microvascular ECs and MFLCs was done on a 6-well plate (BD Falcon) with Cell Culture Inserts (Falcon, 353102, 1.0 microns pore size). Human pulmonary microvascular ECs or pulmonary arterial fibroblast-like cells (at $5 \times 10^{4}$ density) and MFLCs (at $5 \times 10^{4}$ density) were added into the lower or upper chamber with or without rapamycin $(10 \mathrm{nM})$. After two weeks incubation periods, they were assessed microscopically and further characterized by immunohistochemical staining, harvested to extract RNA for PCR array, and other assays.

\section{Magnetic cell sorting (MACS)}

After trypsinization of ECLCs at passage 2, CD31 positive cells were isolated by using CD31 MicroBeads (Direct CD31 progenitor cell isolation kit, Miltenyi Biotec Inc, Auburn, CA, USA) as described previously [13]. After trypsinization of ECLCs at passage 2, $100 \mu \mathrm{l}$ of FcR Blocking Reagent (Direct CD31 progenitor cell isolation kit, Miltenyi Biotec Inc, Auburn, CA, USA) per $10^{8}$ total cells was added to the cell suspension to inhibit nonspecific or Fc-receptor mediated binding of CD31 MicroBeads (Direct CD31 progenitor cell isolation kit, Miltenyi Biotec) to non-target cells. Cells were labeled by adding $100 \mu \mathrm{l} \mathrm{CD31} \mathrm{MicroBeads} \mathrm{per} 10^{8}$ total cells, and incubated for $30 \mathrm{~min}$ at $6-12^{\circ} \mathrm{C}$. After washing, cells were resuspended in $500 \mu \mathrm{l}$ buffer and applied to the MS+/RS+ column with the column adapter in the magnetic field of the MACS separator. The column was washed $3 \times$ with $500 \mu \mathrm{l}$ buffer. The column was removed from the separator and the retained cells were flushed out with $1 \mathrm{ml}$ buffer under pressure using the plunger supplied with the column. The cells were incubated in EGM and cultured until passage 5.

\section{Total RNA isolation and Quantitative measurement}

Total RNA was extracted from human pulmonary microvascular ECs with an RNeasy Mini Kit (Qiagen, CA, USA). RNA and cRNA yields were quantitated on a Nano-Drop ND-1000 UV-Vis Spectrophotometer (NanoDrop Technologies, Wilmington, DE, USA) as described previously [13].

\section{PCR array analysis}

$\mathrm{RT}^{2}$ Profiler ${ }^{\mathrm{TM}}$ PCR Arrays (SABiosciences, Frederick, USA) are the reliable and sensitive tools for analyzing 
the expression of a focused panel of genes in signal transduction pathways, biological process or disease related gene networks. The 96-well plate Human Autophagy PCR-array (PAHS-084) which profiles the expression of 84 key genes involved in autophagy and Human Endothelial Cell Biology PCR-array (PAHS-015) which profiles the expression of 84 genes related to endothelial cell biology were selected as the hypothesis.

There is a better sensitivity of quantitative PCR in comparison to microarray [20,21]. The PCR Arrays can be used for research on various disease including cancer, immunology, and phenotypic analysis of cells.

The mRNA of each co-cultured EC was converted into cDNA using the $\mathrm{RT}^{2}$ First Strand Kit (SABiosciences, Frederick, USA). This cDNA was then added to the $\mathrm{RT}^{2}$ SYBR Green qPCR Master Mix (SABiosciences, Frederick, USA). Next, each sample was aliquotted on PCR-arrays. All steps were done according to the manufacturer's protocol for the ABI Prism 7000 Sequence Detection System. To analyze the PCR-array data, an MS-Excel sheet with macros was downloaded from the manufacturer's website http://www.sabiosciences.com/ pcrarraydataanalysis.php. The website also allowed online analysis. For each PCR reaction, the excel sheet calculated two normalized average $C_{\mathrm{t}}$ values, a paired $t$ test $P$ value and a fold change. Data normalization was based on correcting all $C_{t}$ values for the average $C_{t}$ values of several constantly expressed housekeeping genes (HKGs) present on the array. PCR-array analysis results were evaluated.

\section{SMAD reporter assay}

The SMAD reporter assay detects the activity of TGF $\beta$ signaling pathway through monitoring the SMAD transcriptional response in cultured cells. Cignal SMAD Reporter (GFP) Kit (SABiosciences, Frederick, USA) was adapted to assess the activity of this signaling pathway.

Co-cultured human pulmonary microvascular ECs with pulmonary arterial fibroblast-like cells or MFLCs were trypsinized, suspended at $1 \times 10^{4} /$ well at density, and seeded into 96 -well cell culture plates. Transfection complexes including the signal reporters were aliquoted into wells containing overnight cell cultures. After 40 hours of transfection, expression of the GFP reporter was monitored via the fluorometry (Infinite 200 PRO, Tecan Group Ltd., Männedorf, Switzerland). All steps were done according to the manufacturer's protocol.

\section{Reactive oxygen species (ROS) assay}

Measuring ROS activity intracellularly, we adapted OxiSelect ROS assay kit (Cell Biolabs, Inc., San Diego, USA).

Co-cultured human pulmonary microvascular ECs with pulmonary arterial fibroblast-like cells or MFLCs were trypsinized, suspended at $1 \times 10^{4} /$ well at density, and seeded into 96-well cell culture plates. Media was removed from all wells and cells were washed with DPBS 3 times. $100 \mu \mathrm{L}$ of $1 \times 2$,7-dichlorofluorescein diacetate (DCFH)-DA/media solution added to cells and they were incubated at $37^{\circ}$ for 60 minutes. Solution was removed and cells were washed with DPBS 3 times. DCFH-DA loaded cells were treated with hydrogen peroxide $(100 \mu \mathrm{M})$ in $100 \mu \mathrm{L}$ medium. After 1 hour, the fluorescence was read via the fluorometry (Infinite 200 PRO, Tecan Group Ltd., Männedorf, Switzerland). All steps were done according to the manufacturer's protocol.

\section{Statistical analysis}

Three independent experiments were performed and subjected to statistical analysis. The results were expressed as the means \pm SEM. PCR array data were analyzed using a paired $t$ test according to the manufacturer's protocol and other data were the Mann-Whitney $\mathrm{U}$ test. A p $<0.05$ was considered to be significant for all comparisons.

\section{Results}

The cellular composition of endarterectomized tissue from CTEPH patients

Two different cell types were isolated from the "distal" vascular tissue in the patients with CTEPH. The cell types were determined by morphology to be ELCs (rounded appearance and cell-cell contact in the monolayer) and MFLCs (spindle-shaped with cytoplasmic extensions) (Figure 1). They were dissociated and passaged free from surrounding cells using cloning cylinders. MFLCs were prepared from each of the six patients and ELCs could be isolated from 4 of the six patients.

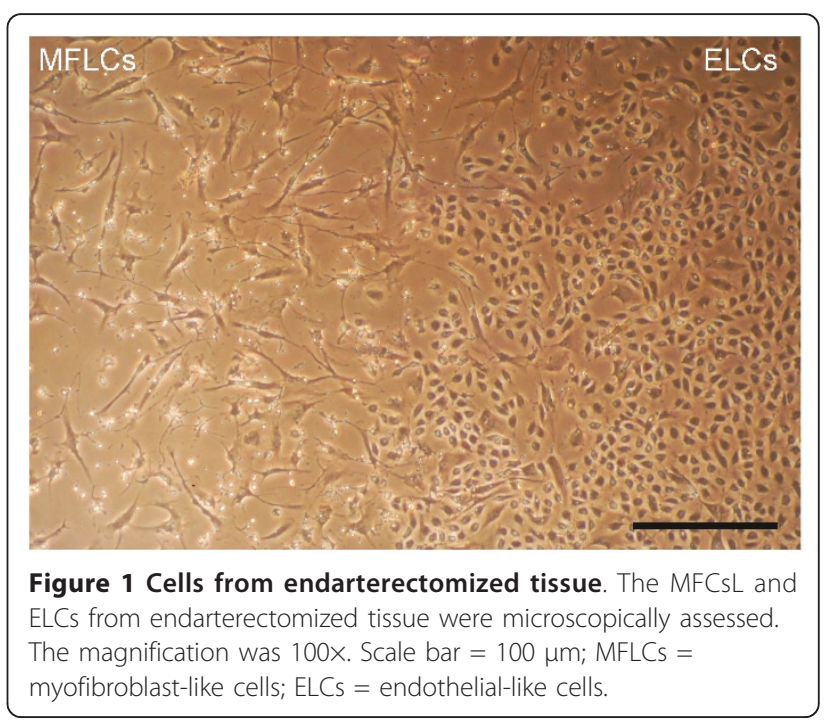


Moreover, another cell type was isolated from the vessel wall tissues of control pulmonary arteries, defined morphologically as fibroblast-like cells (pulmonary arterial fibroblast-like cells) (data not shown). These cells were used as control cells, and were prepared in the same way as the CTEPH specimens.

The cells outgrown from the organized thrombotic tissue and control pulmonary arteries were further characterized by immunohistochemical staining for desmin, vimentin, von Willebrand factor (Factor VIII) and $\alpha$ SMA. ELCs were positively stained for the endothelial cell (EC)-specific marker (Factor VIII) and the mesenchymal-specific marker (vimentin) and negative for the 2 smooth muscle cell (SMC)-specific markers (desmin and $\alpha$-SMA) [12]. MFLCs were Factor VIII and desmin negative and vimentin and $\alpha$-SMA positive [12]. Pulmonary arterial fibroblast-like cells were Factor VIII, desmin and $\alpha$-SMA negative, and vimentin positive (data not shown).

\section{Phenotypic alteration of ELCs}

After a few passages, morphological alterations were detected in the ELCs. The cell-cell contact of the endothelial monolayers became disrupted, and some ELCs had lost their rounded appearance and acquired an elongated, mesenchymal-like morphology. At the 2nd passages, the morphological alterations could not to be detected microscopically (Figure 2A), but some SM-like cells (as defined by expression of $\alpha$-SMA) (Figure 2B) and a few transitional cells (co-expressing both endothelial- and SM-cell markers) were consistently observed (Figure 2C) by immunohistochemical staining. These transitional cells could be observed in ELCs prepared from 4 of the six samples.

Since this result suggested that ELCs were contaminated with SMCs, at the 3rd passage, they were sorted for the EC marker CD31 in order to establish that the ELCs were free of contamination with SMCs. After magnetic cell sorting for the EC marker CD31, ELCs were examined microscopically, and unusual "pile" growth and disrupted formation of the endothelial monolayer were detected (Figure 2D). Moreover, SMlike cells (Figure 2E) and transitional cells were consistently observed (Figure 2F).

\section{Transitional cells in endarterectomized CTEPH tissue}

To detect transitional cells which co-express both endothelial (CD31) and SM ( $\alpha$-SMA) markers in the PEA tissues of patients with CTEPH, a double immunostaining method for CD31/ $\alpha$-SMA was performed. The HE staining of the neointimal layers of both the "proximal" and the "distal" vascular tissues indicated the presence of a fibrin network, and nuclei are seen within this region (Figure 2G). These neointimal layers are composed of some $\alpha$-SMA positive cells (Figure $2 \mathrm{H}$ ).
Although the neointimal layers of both the "proximal" and the "distal" vascular tissues were composed of $\alpha$ SMA positive cells, CD31 positive cells were found in the "distal" vascular wall tissue but not in the "proximal" vascular tissue (Figure 2I). As shown in Figure 2J, a few CD31 and $\alpha$-SMA double-positive cells were identified in the "distal" vascular tissues, thus indicating the presence of "intermediate" cells, which were intermediate between ECs and muscle cells in structure, in the neointimal lesions of CTEPH patients.

\section{Decreased expression of Autophagic marker LC3} (microtubule-associated protein 1 light chain 3; MAP1LC3), abnormal mitochondria, and decreased expression of superoxide dismutase (SOD)-2 in ELCs

To assess ELC alterations, an immunofluorescence staining method for LC3, mitochondrial marker mitotracker red, and SOD-2 was performed.

LC3 is a major constituent of the autophagosome, a double-membrane structure that sequesters the target organelle/protein and then fuses with endo/lysosomes where the contents and LC3 are degraded. Confocal microscopy showed that the ELCs did not express LC3. The formation of autophagosomes (green punctate structures) was not detected in these cells (Figure $2 \mathrm{~K}$ ).

SOD-2 is an enzyme that catalyzes the dissociation of superoxide into oxygen and hydrogen peroxide. As such, this is an important antioxidant defense in nearly all cells exposed to oxygen and is located in the mitochondria. Immunofluorescence staining for mitochondrial marker mitotracker red revealed that the normal filamentous mitochondrial reticulum was disrupted and rarefied in ELCs (Figure 2L). Moreover, SOD-2 was decreased in ELCs (Figure 2M).

\section{Phenotypic alteration of human pulmonary microvascular ECs is induced by MFLCs-conditioned medium}

As mentioned above, ELCs isolated from the PEA tissues could easily change their phenotype during passaging. We postulated that the interactions of ELCs and MFLCs, which exist in close contact in the PEA tissues, are involved in a process of organized thrombus formation that occurs during the development of CTEPH. One basic component of this interaction may be the MFLC-induced transition of ELCs. To test this hypothesis, the commercially available human pulmonary microvascular ECs were incubated in serum-free medium conditioned by MFLCs to determine whether MFLCs release mediators which cause phenotypic alteration of human pulmonary microvascular ECs.

We first established that the human pulmonary microvascular ECs were free of contamination with vascular smooth muscle cells (VSMCs) by morphology (rounded appearance and cell-cell contact of the monolayer) 


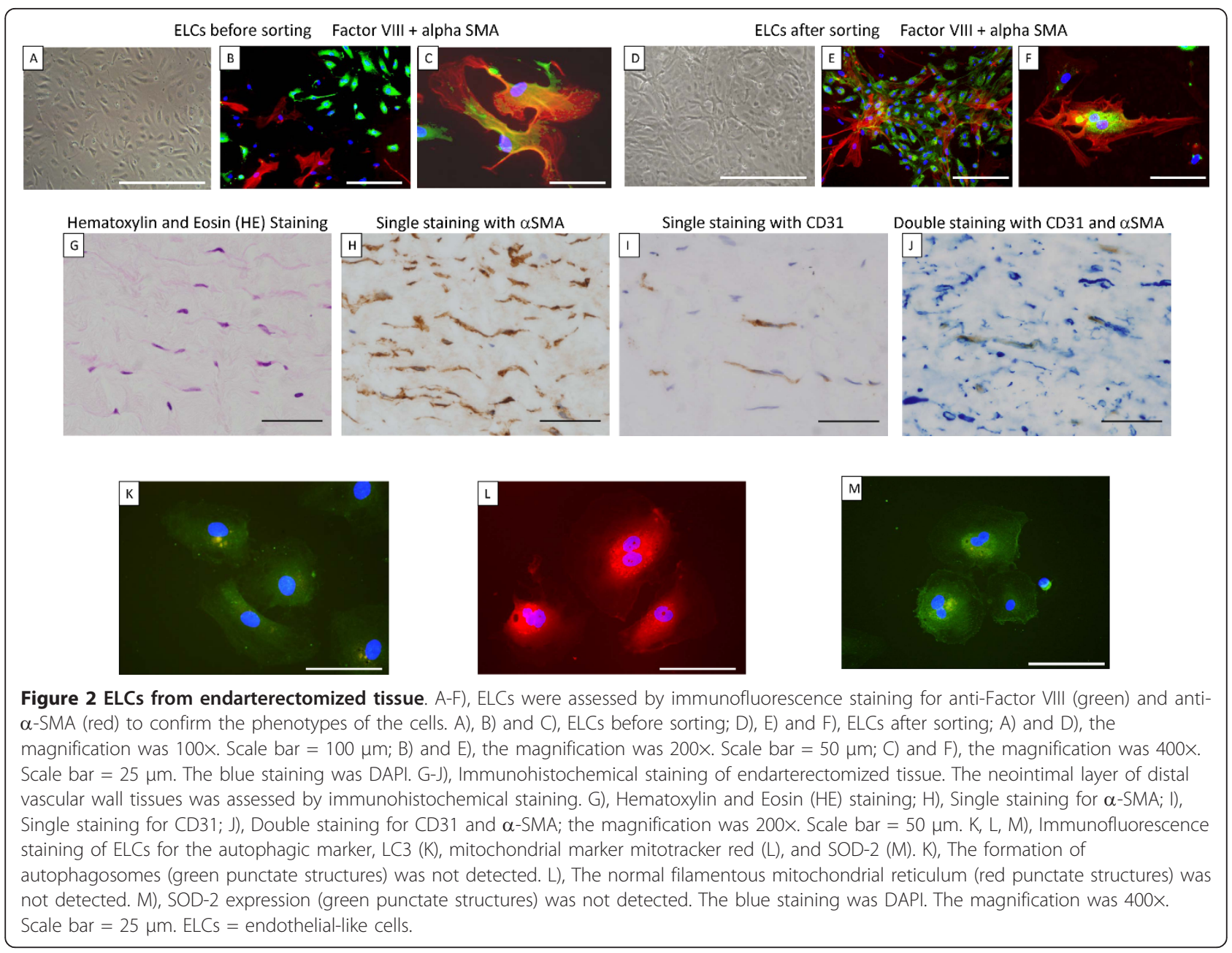

(Figure 3A) and by immunofluorescence staining using anti-von Willebrand factor (Figure 3D), anti- $\alpha$-SMA (Figure 3D), anti-vimentin (data not shown), and antihuman desmin (data not shown) antibodies. The endothelial cell-specific marker and the mesenchymalspecific marker were positive, and the 2 smooth musclespecific markers were negative, providing evidence that the human pulmonary microvascular ECs were not contaminated with VSMCs.

At the 2nd passage after incubation in serum-free medium conditioned by pulmonary arterial fibroblastlike cells and MFLCs, the phenotypic alteration of human pulmonary microvascular ECs was assessed microscopically and by immunofluorescence staining. The cell-cell contact of the endothelial monolayers became disrupted, and many ECs had lost their rounded appearance and acquired an elongated, mesenchymallike morphology in the medium conditioned by MFLCs (Figure $3 \mathrm{C}$ ) in comparison to the medium conditioned by pulmonary arterial fibroblast-like cells (Figure 3B). The number of ECs (as defined by expression of von
Willebrand factor) decreased, and SM-like cells (as defined by expression of $\alpha$-SMA) were consistently observed in the medium conditioned by MFLCs (Figure $3 \mathrm{~F}, \mathrm{G})$, but not in the medium conditioned by pulmonary arterial fibroblast-like cells (Figure 3E, G).

\section{Expression of TGF- $\beta 1$ protein in the conditioned medium} Because TGF- $\beta 1$ is known to be involved in inducing the endothelial-mesenchymal transition [22] and is known to promote $\alpha$-SMA expression in non-muscle cells (ECs and fibroblasts derived from various tissues) [23,24], the protein levels in the conditioned medium were measured by ELISA. Serum-free medium conditioned by MFLCs contained higher TGF- $\beta 1$ levels than medium conditioned by pulmonary arterial fibroblast-like cells, but the difference was not statistically significant (Figure 3H).

\section{Phenotypic alteration of human pulmonary microvascular ECs co-cultured with MFLCs}

After a 14 day incubation period, morphological alterations were detected in human pulmonary microvascular 
$2^{\text {nd }}$ passage day 10 after treatment with the conditioned medium
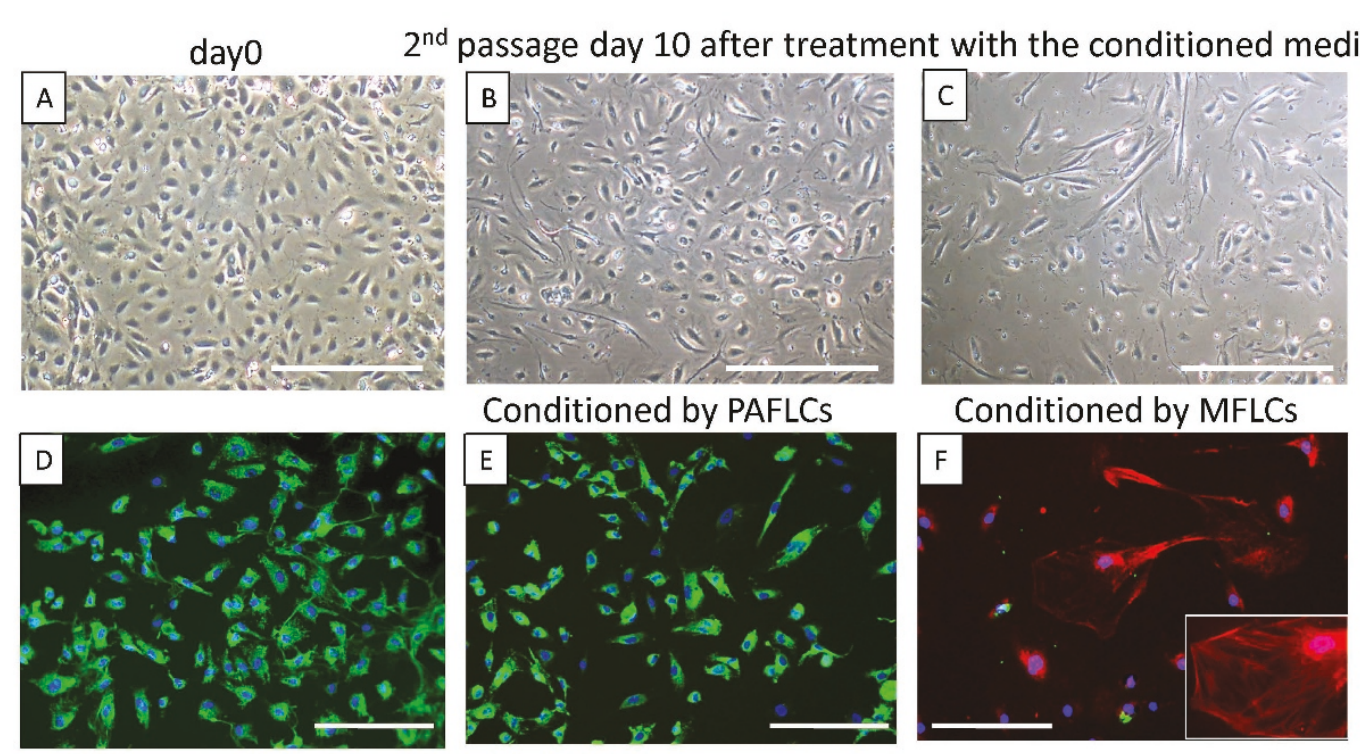

\section{Conditioned by MFLCS}

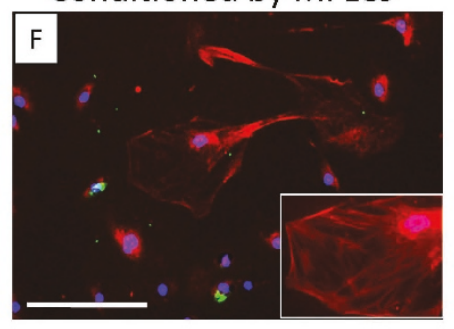

$\mathrm{H}$
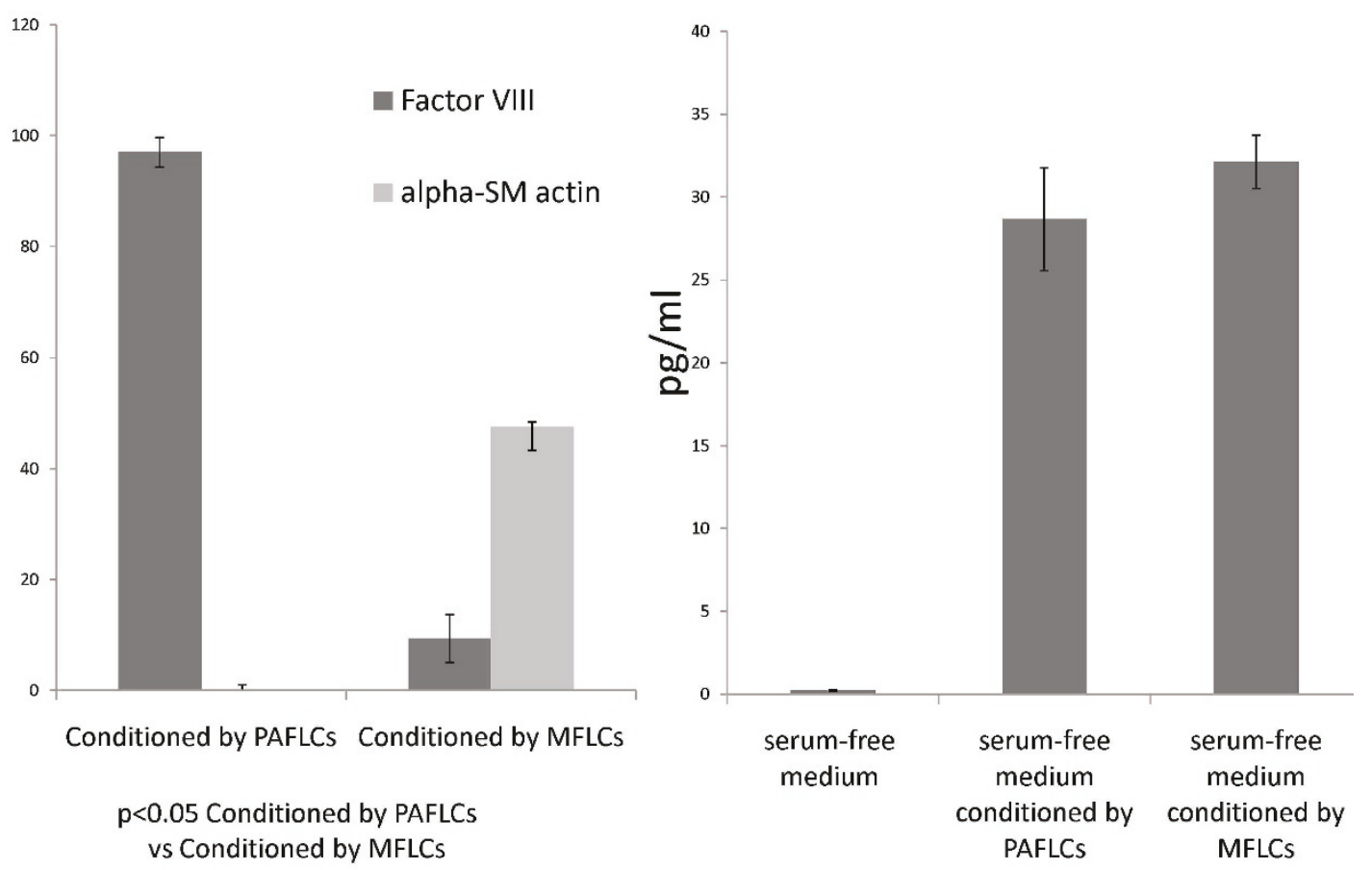

Figure 3 Human pulmonary microvascular ECs (HPMVECs) in serum-free medium conditioned by pulmonary arterial fibroblast-like cells (PAFLCs) or myofibroblast-like cells (MFLCs). The phenotypic alteration of HPMVECs was assessed microscopically and by

immunofluorescence staining. A) and D), Before incubation in serum-free medium conditioned by PAFLCs and MFLCs; B) and E), At the 2nd passage after incubation in serum-free medium conditioned by PAFLCs; C) and F), At the 2nd passage after incubation in serum-free medium conditioned by MFL(s; A), B) and C), microscopic findings; the magnification was 100x. Scale bar = $100 \mu$ m; D), E) and F), Immunofluorescence staining for anti-Factor VIII (green) and anti- $\alpha$-SMA (red). The blue staining was DAPI. The magnification was 200x. Scale bar $=50 \mu \mathrm{m}$. F), Some cells were positive for smooth muscle actin fibers (see inset); HPMVECs = human pulmonary microvascular endothelial cells; MFLCs =

myofibroblast like cells; PAFLCs = fibroblast-like cells from control pulmonary arteries. G) Positive cells for anti-von Willebrand factor and anti- $\alpha$ SM-actin were counted in 3 different fields at a magnification of $\times 200$ in a fluorescence microscope. ${ }^{*} P<0.05$ vs. PAFLCs, $n \geq 3$. H) The TGF- $\beta 1$ protein levels in the conditioned medium were measured by ELISA. There were no significant differences between the serum-free medium conditioned by PAFLCS and MFLCS. 
ECs co-cultured with MFLCs (Figure 4B, D), but not those cultured with pulmonary arterial fibroblast-like cells (Figure 4A, C). The cell-cell contact of the endothelial monolayers (Figure 4A) became disrupted, and hill and valley formation appeared. Moreover, some ECs had lost their rounded appearance and acquired an elongated, mesenchymal-like morphology (Figure 4B). Some SM-like cells (as defined by their expression of $\alpha$ SMA) and a few transitional cells (co-expressing both endothelial- and SM- cell markers) were consistently

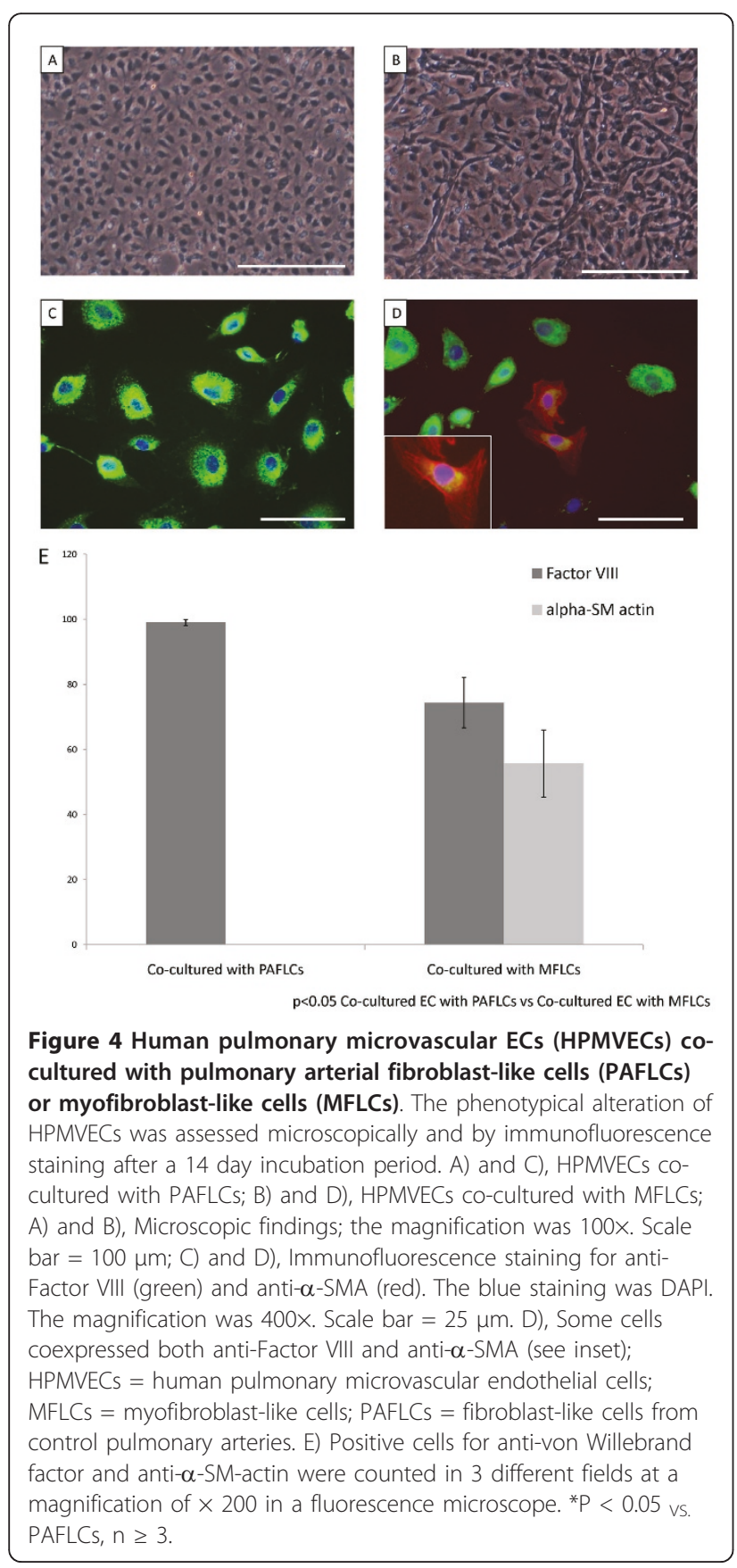

observed (Figure 4D, E) by immunohistochemical staining.

\section{Autophagy PCR array analysis of human pulmonary microvascular ECs co-cultured with MFLCs}

There were decreases in the expression of 17 autophagy-related genes in ECs co-cultured with MFLCs in comparison to the expression in ECs co-cultured with pulmonary arterial fibroblast-like cells (Figure 5A) (Table 1). Four of these genes; AMBRA1, ATG4D, MAP1LC3B, and RGS19, are involved in autophagic vacuole formation. In particular, ATG4D is responsible for protein targeting to the membrane/vacuole, and is responsible for protein transport and protease activity. Ten of the 17 genes; BCL2, BID, CDKN2A, CTSB, HSP90AA1, HTT, IFNG, IGF1, INS, and PRKAA1 are co-regulators of autophagy and apoptosis. Three genes; RPS6KB1, TMEM77, and UVRAG are related to autophagy in response to other intracellular signals.

\section{Autophagic marker LC3 expression in human pulmonary microvascular ECs co-cultured with MFLCs}

Confocal microscopy showed that the ECs co-cultured with pulmonary arterial fibroblast-like cells expressed LC3. The formation of autophagosomes (green punctate structures) was detected in these cells (Figure 6A), but not in ECs co-cultured with MFLCs (Figure 6B) nor in ELCs (Figure 2K).

\section{Abnormal mitochondria and decreased expression of superoxide dismutase (SOD)-2 in human pulmonary microvascular ECs co-cultured with MFLCs}

Immunofluorescence staining for mitochondrial marker mitotracker red revealed that the normal filamentous mitochondrial reticulum observed in ECs co-cultured with pulmonary arterial fibroblast-like cells (Figure 6D) was disrupted and rarefied in both ECs co-cultured with MFLCs (Figure 6E) and ELCs (Figure 2L). Moreover, SOD-2 was decreased in ECs co-cultured with MFLCs (Figure 6H) and ELCs (Figure 2M) compared to those co-cultured with pulmonary arterial fibroblast-like cells (Figure 6G). The decrease in SOD-2 expression in ECs co-cultured with MFLCs and ELCs might be associated with a reduction in SOD-2 activity.

\section{Endothelial cell biology PCR array of human pulmonary microvascular ECs co-cultured with MFLCs}

These results, including the phenotypic alterations, inactivation of autophagy, and mitochondrial dysfunction, suggested that the endothelial cell biology is altered in patients with CTEPH. Therefore, an endothelial cell biology PCR array was done to further explore the effects of MFLCs on endothelial cell biology. 


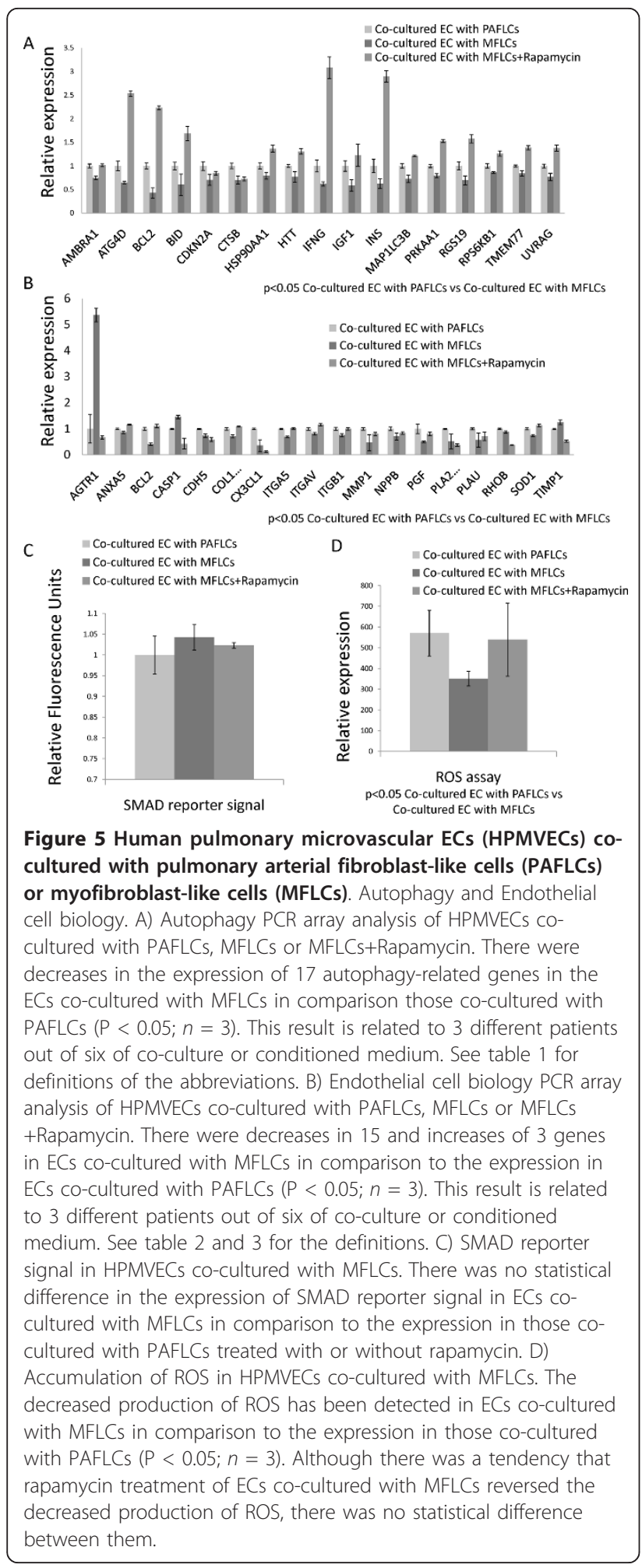

There were decreases in the expression of 15 and increases in the expression of 3 genes in ECs co-cultured with MFLCs in comparison to the expression in those co-cultured with pulmonary arterial fibroblast-like cells (Figure 5B). The 15 decreased genes were ANXA5, BCL2, CDH5, COL18A1, CX3CL1, ITGA5, ITGAV, ITGB1, MMP1, NPPB, PGF, PLA2G4C, PLAU, RHOB, and SOD1 (Table 2). CDH5, COL18A1, CX3CL1, ITGA5, ITGAV, ITGB1 and RHOB are related to endothelial cell activation as adhesion molecules. MMP1, NPPB, PLAU and RHOB are related to endothelial cell activation, and are part of the extracellular matrix (ECM) molecules. ANXA5 and PLAU are related to endothelial cell activation with regard to thrombin activity. PGF is related to angiogenesis. PLA2G4C and SOD-1 are both related to the endothelial cell response to stress.

The 3 genes with increased expression were AGTR1, CASP1, and TIMP1 (Table 3). AGTR1 is related to the permissibility and vessel tone of the angiotensin system. CASP1 is related to endothelial cell injury and resulting apoptosis. TIMP1 is related to endothelial cell activation and cell growth.

\section{SMAD reporter signal in human pulmonary microvascular} ECs co-cultured with MFLCs

The SMAD2 and SMAD3 proteins are phosphorylated and activated by TGF- $\beta$ signaling. These activated SMAD 2 and SMAD 3 then form complexes with the SMAD4. These SMAD complexes then migrate to the nucleus, where they activate the expression of TGF- $\beta$ responsive genes.

Besides simple concentration measurements of TGF$\beta 1$ in the conditioned medium (Figure $3 \mathrm{H}$ ), the activation of the TGF- $\beta$ signaling in human pulmonary microvascular ECs co-cultured with MFLCs were measured by the SMAD reporter assay. There was no statistical difference in the expression of SMAD reporter signal in ECs co-cultured with MFLCs in comparison to the expression in those co-cultured with pulmonary arterial fibroblast-like cells (Figure 5C).

\section{Accumulation of ROS in human pulmonary microvascular ECs co-cultured with MFLCs}

Accumulation of ROS coupled with an increase in oxidative stress has been implicated in the pathogenesis of numerous disease states. As SOD1 and SOD2 downregulation have been shown by the PCR-Arrays (Figure $5 \mathrm{~B}$ ) and immunofluorescence (Figure $6 \mathrm{H}$ ), the missing production of ROS might be involved in ECs co-cultured with MFLCs [25]. The decreased production of ROS has been detected in ECs co-cultured with MFLCs in comparison to the expression in those co-cultured with pulmonary arterial fibroblast-like cells (Figure 5D).

\section{Rapamycin treatment}

Prolonged rapamycin treatment of ECs co-cultured with MFLCs reversed the decrease in the 17 autophagy- 


\begin{tabular}{|c|c|c|c|c|}
\hline Biological process description & Gene name & $\begin{array}{c}\text { Gene } \\
\text { symbol }\end{array}$ & Public ID & P-value \\
\hline $\begin{array}{c}\text { Autophagy Machinary Components: Genes Involved in } \\
\text { Autophagic Vacuole Formation }\end{array}$ & Autophagy/beclin-1 regulator 1 & AMBRA1 & NM_017749 & 0.00308 \\
\hline $\begin{array}{c}\text { Autophagy Machinary Components: Genes Involved in } \\
\text { Autophagic Vacuole Formation } \\
\text { Genes Responsible for Protein Targeting to Membrane/ } \\
\text { Vacuole } \\
\text { Genes Responsible for Protein Transport } \\
\text { Genes with Protease Activity }\end{array}$ & $\begin{array}{c}\text { ATG4 autophagy related } 4 \text { homolog D ( } \mathrm{S} . \\
\text { cerevisiae) }\end{array}$ & ATG4D & $\begin{array}{l}\text { NM_032885 } \\
\text { NM_017749 }\end{array}$ & 0.01167 \\
\hline $\begin{array}{l}\text { Regulation of Autophagy: } \\
\text { Co-Regulators of Autophagy and Apoptosis }\end{array}$ & B-cell CLL/lymphoma 2 & $\mathrm{BCL} 2$ & NM_000633 & 0.000727 \\
\hline $\begin{array}{l}\text { Regulation of Autophagy: } \\
\text { Co-Regulators of Autophagy and Apoptosis }\end{array}$ & $\mathrm{BH} 3$ interacting domain death agonist & $\mathrm{BID}$ & NM_001196 & 0.047933 \\
\hline $\begin{array}{l}\text { Regulation of Autophagy: } \\
\text { Co-Regulators of Autophagy and Apoptosis }\end{array}$ & $\begin{array}{l}\text { Cyclin-dependent kinase inhibitor 2A } \\
\text { (melanoma, p16, inhibits CDK4) }\end{array}$ & CDKN2A & NM_000077 & 0.044888 \\
\hline $\begin{array}{l}\text { Regulation of Autophagy: } \\
\text { Co-Regulators of Autophagy and Apoptosis }\end{array}$ & Cathepsin B & CTSB & NM_001908 & 0.010802 \\
\hline $\begin{array}{l}\text { Regulation of Autophagy: } \\
\text { Chaperone-Mediated Autophagy }\end{array}$ & $\begin{array}{c}\text { Heat shock protein } 90 \mathrm{kDa} \text { alpha (cytosolic), } \\
\text { class A member } 1\end{array}$ & HSP90AA1 & NM_001017963 & 0.037151 \\
\hline $\begin{array}{l}\text { Regulation of Autophagy: } \\
\text { Co-Regulators of Autophagy and Apoptosis }\end{array}$ & Huntingtin & $\mathrm{HTT}$ & NM_002111 & 0.033212 \\
\hline $\begin{array}{l}\text { Regulation of Autophagy: } \\
\text { Co-Regulators of Autophagy and Apoptosis } \\
\text { Co-Regulators of Autophagy and the Cell Cycle }\end{array}$ & Interferon, gamma & IFNG & NM_000619 & 0.017749 \\
\hline $\begin{array}{l}\text { Regulation of Autophagy: } \\
\text { Co-Regulators of Autophagy and Apoptosis }\end{array}$ & Insulin-like growth factor 1 (somatomedin C) & IGF1 & NM_000618 & 0.017282 \\
\hline $\begin{array}{l}\text { Regulation of Autophagy: } \\
\text { Co-Regulators of Autophagy and Apoptosis }\end{array}$ & Insulin & INS & NM_000207 & 0.045037 \\
\hline $\begin{array}{c}\text { Autophagy Machinary Components: Genes Involved in } \\
\text { Autophagic Vacuole Formation }\end{array}$ & $\begin{array}{c}\text { Microtubule-associated protein } 1 \text { light chain } 3 \\
\text { beta }\end{array}$ & MAP1LC3B & NM_022818 & 0.011251 \\
\hline $\begin{array}{c}\text { Regulation of Autophagy: } \\
\text { Co-Regulators of Autophagy and Apoptosis } \\
\text { Autophagy in Response to Other Intracellular Signals }\end{array}$ & $\begin{array}{c}\text { Protein kinase, AMP-activated, alpha } 1 \text { catalytic } \\
\text { subunit }\end{array}$ & PRKAA1 & NM_006251 & 0.005633 \\
\hline $\begin{array}{c}\text { Autophagy Machinary Components: Genes Involved in } \\
\text { Autophagic Vacuole Formation }\end{array}$ & Regulator of G-protein signaling 19 & RGS19 & NM_005873 & 0.021592 \\
\hline $\begin{array}{l}\text { Regulation of Autophagy: } \\
\text { Autophagy in Response to Other Intracellular Signals }\end{array}$ & $\begin{array}{l}\text { Ribosomal protein } \mathrm{S6} \text { kinase, } 70 \mathrm{kDa} \text {, } \\
\text { polypeptide } 1\end{array}$ & RPS6KB1 & NM_003161 & 0.024072 \\
\hline $\begin{array}{l}\text { Regulation of Autophagy: } \\
\text { Autophagy in Response to Other Intracellular Signals }\end{array}$ & Transmembrane protein 77 & TMEM77 & NM_178454 & 0.019285 \\
\hline $\begin{array}{c}\text { Regulation of Autophagy: } \\
\text { Autophagy in Response to Other Intracellular Signals }\end{array}$ & UV radiation resistance associated gene & UVRAG & NM_003369 & 0.016479 \\
\hline
\end{tabular}

Functional classification of low expressed genes in co-cultured HPMVECs with MFLCs in comparison to PAFLCs

related genes (Figure 5A) (Table 1) and prevented the changes in expression in 11 of the 15 decreased and all three of the increased genes related to endothelial cell biology (Figure 5B) (Table 2, 3). There was no statistical difference in the expression of SMAD reporter signal in ECs co-cultured with MFLCs with rapamycin (Figure 5C). Although rapamycin treatment of ECs co-cultured with MFLCs seemed to reverse the decreased production of ROS (Figure 5D), there was no statistical difference between them.

Confocal microscopy showed that the ECs co-cultured with MFLCs that were treated with rapamycin expressed LC3. Although the formation of autophagosomes (green punctate structures) was not detected in ECs co- cultured with MFLCs (Figure 6B), it was detected in these cells when they were treated with rapamycin (Figure $6 \mathrm{C}$ ). In the ECs co-cultured with MFLCs, the colocalization of Mitotracker red and SOD-2 was lost, indicating that the mitochondrial reticulum is disrupted (Figure 6E, 2M). However, the mitochondria in the ECs co-cultured with MFLCs that were treated with rapamycin form an intricate, filamentous network, in which SOD-2 and Mitotracker red are tightly co-localized (Figure $6 \mathrm{~F}, \mathrm{I})$.

\section{Discussion}

EnMT is a term which has been used to describe the process through which ECs lose their endothelial 

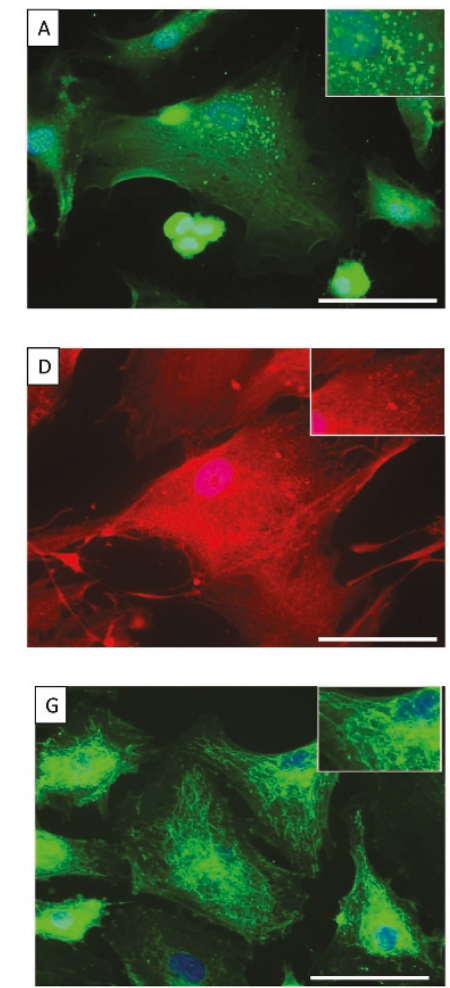
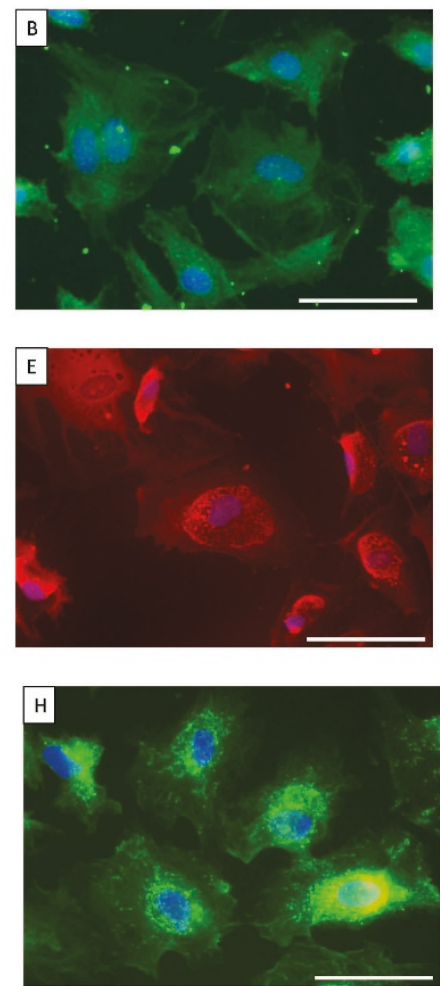
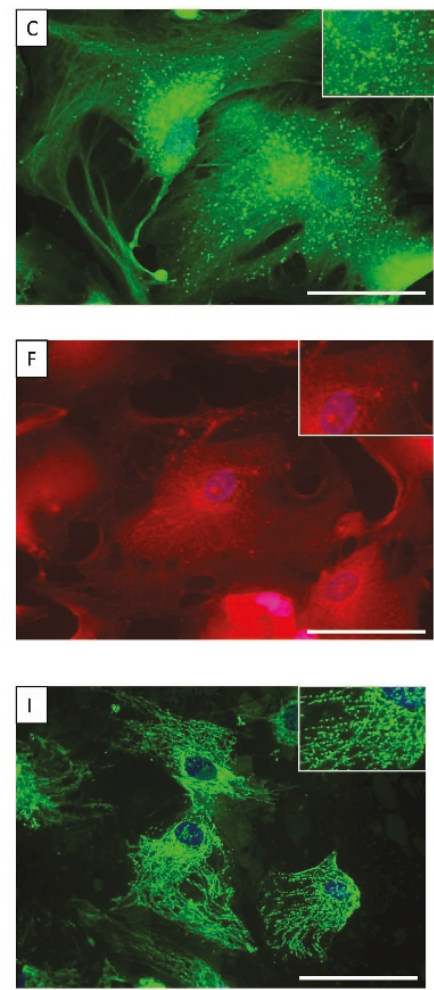

Figure 6 Immunofluorescence staining of human pulmonary microvascular ECs (HPMVECs) and endothelial-like cells (ELCs) for the autophagic marker, LC3 (A-C), mitochondrial marker mitotracker red (D-F), and SOD-2 (G-I). A), HPMVECS CO-Cultured with PAFLCs; B), with MFLCs; C), with MFLCs + Rapamycin; A) and C), The formation of autophagosomes (green punctate structures) was detected (see inset). D), HPMVECs co-cultured with PAFLCs; E), MFLCs; F), with MFLCs + Rapamycin; D) and F), The normal filamentous mitochondrial reticulum (red punctate structures) was detected (see inset). G), HPMVECs co-cultured with PAFLCs; H), with MFLCs; I), with MFLCs + Rapamycin; G) and I), SOD2 expression (green punctate structures) was detected (see inset). The blue staining was DAPI. The magnification was $400 \times$. Scale bar $=25 \mu \mathrm{m}$. ELCs = endothelial-like cells.

characteristics and gain expression of mesenchymal, myofibroblast-like characteristics [26]. In the present study, a few transitional cells (co-expressing both endothelial- and SM- cell markers) were shown in the primary culture of endarterectomized tissue specimen (Figure 2C, F). The microenvironment created by the stabilized clot is suggested to induce EnMT (Figure 3F, G, 4D, E). Moreover, CD31 and $\alpha$-SMA double-positive cells were identified in the neointimal layer of vascular wall tissue, thus indicating the presence of transitional cells in the neointimal lesions of CTEPH (Figure 2J). In support of our finding, Yao et al showed the presence of CD34 (endothelial marker) positive cells co-expressing $\alpha$-SMA (SM-cell marker) in endarterectomized tissues from patients with CTEPH [27]. Moreover, they suggested that the microenvironment provided by thromboemboli might promote the putative progenitor cells to differentiate and enhance intimal remodeling [27]. In this study, our data suggest that MFLC-related EnMT may enhance intimal remodeling. However, we fully realize the limitations of our data interpretation, which was based on in vitro studies of cultured cells, and acknowledge that data provided in this study were not strong to support EnMT hypothesis because this study failed to show mechanisms responsible for this process. Moreover, it may be possible that transitional cells are more likely progenitor cells rather than they are transdifferentiated by EnMT.

There was no significant difference in TGF- $\beta 1$ levels between serum-free medium conditioned by MFLCs and by pulmonary arterial fibroblast-like cells (Figure $3 \mathrm{H}$ ). Moreover, there was no statistical difference in the expression of SMAD reporter signal in ECs co-cultured with MFLCs in comparison to the expression in those co-cultured with pulmonary arterial fibroblast-like cells (Figure 5C). A recent study provides evidence that Ras/ MAPK, via TGF- $\beta 1$ signaling, mediates completion of EnMT in a bleomycin model of pulmonary fibrosis [28]. However, an endothelial cell biology PCR array in this study demonstrated the decreased expression of RHOB (Ras homolog gene family, member B) in co-cultured human pulmonary microvascular ECs with MFLCs in 
Table 2 Endothelial Cell Biology PCR Array

\begin{tabular}{|c|c|c|c|c|}
\hline $\begin{array}{l}\text { Biological process } \\
\text { description }\end{array}$ & Gene name & $\begin{array}{c}\text { Gene } \\
\text { symbol }\end{array}$ & Public ID & P-value \\
\hline $\begin{array}{l}\text { Endothelial Cell Activation: } \\
\text { Thrombin Activity }\end{array}$ & Annexin A5 & ANXA5 & NM_001154 & 0.023464 \\
\hline $\begin{array}{l}\text { Endothelial Cell Injury: } \\
\text { Response to Stress } \\
\text { Anti-Apoptosis }\end{array}$ & B-cell CLL/lymphoma 2 & $\mathrm{BCL} 2$ & NM_000633 & 0.000247 \\
\hline $\begin{array}{l}\text { Endothelial Cell Activation: } \\
\text { Adhesion Molecules }\end{array}$ & Cadherin 5, type 2 (vascular endothelium) & $\mathrm{CDH} 5$ & NM_001795 & 0.003968 \\
\hline $\begin{array}{l}\text { Endothelial Cell Activation: } \\
\text { Adhesion Molecules }\end{array}$ & Collagen, type XVIII, alpha 1 & COL18A1 & NM_030582 & 0.004024 \\
\hline $\begin{array}{l}\text { Endothelial Cell Activation: } \\
\text { Adhesion Molecules }\end{array}$ & Chemokine (C-X3-C motif) ligand 1 & CX3CL1 & NM_002996 & 0.000779 \\
\hline $\begin{array}{l}\text { Endothelial Cell Activation: } \\
\text { Adhesion Molecules }\end{array}$ & Integrin, alpha 5 (fibronectin receptor, alpha polypeptide) & ITGA5 & NM_002205 & 0.000147 \\
\hline $\begin{array}{l}\text { Endothelial Cell Activation: } \\
\text { Adhesion Molecules }\end{array}$ & Integrin, alpha V (vitronectin receptor, alpha polypeptide, antigen CD51) & ITGAV & NM_002210 & 0.02125 \\
\hline $\begin{array}{l}\text { Endothelial Cell Activation: } \\
\text { Adhesion Molecules }\end{array}$ & $\begin{array}{c}\text { Integrin, beta } 1 \text { (fibronectin receptor, beta polypeptide, antigen CD29 } \\
\text { includes MDF2, MSK12) }\end{array}$ & ITGB1 & NM_002211 & 0.018399 \\
\hline $\begin{array}{c}\text { Endothelial Cell Activation: } \\
\text { Extracellular Matrix (ECM) } \\
\text { Molecules }\end{array}$ & Matrix metallopeptidase 1 (interstitial collagenase) & MMP1 & NM_002421 & 0.021783 \\
\hline $\begin{array}{c}\text { Permissibility and Vessel Tone: } \\
\text { Regulation of Blood Pressure } \\
\text { Regulation of Vascular } \\
\text { Permeability } \\
\text { Angiogenesis: } \\
\text { Negative Regulation of } \\
\text { Angiogenesis } \\
\text { Endothelial Cell Activation: } \\
\text { Extracellular Matrix (ECM) } \\
\text { Molecules }\end{array}$ & Natriuretic peptide precursor B & NPPB & NM_002521 & 0.041345 \\
\hline $\begin{array}{c}\text { Angiogenesis: } \\
\text { Other Genes Involved in } \\
\text { Angiogenesis }\end{array}$ & Placental growth factor & PGF & NM_002632 & 0.029734 \\
\hline $\begin{array}{l}\text { Endothelial Cell Injury: } \\
\text { Response to Stress }\end{array}$ & Phospholipase A2, group IVC (cytosolic, calcium-independent) & PLA2G4C & NM_003706 & 0.014626 \\
\hline $\begin{array}{c}\text { Endothelial Cell Activation: } \\
\text { Extracellular Matrix (ECM) } \\
\text { Molecules } \\
\text { Thrombin Activity }\end{array}$ & Plasminogen activator, urokinase & PLAU & NM_002658 & 0.039877 \\
\hline $\begin{array}{l}\text { Endothelial Cell Activation } \\
\text { Adhesion Molecules } \\
\text { Angiogenesis: } \\
\text { Positive Regulation of } \\
\text { Angiogenesis } \\
\text { Endothelial Cell Activation: } \\
\text { Adhesion Molecules } \\
\text { Endothelial Cell Injury: } \\
\text { Other Genes Related to } \\
\text { Apoptosis }\end{array}$ & Ras homolog gene family, member B & $\mathrm{RHOB}$ & NM_004040 & 0.035874 \\
\hline $\begin{array}{l}\text { Endothelial Cell Injury: } \\
\text { Response to Stress }\end{array}$ & Superoxide dismutase 1, soluble & SOD1 & NM_000454 & 0.001855 \\
\hline
\end{tabular}

Functional classification of low expressed genes in co-cultured HPMVECs with MFLCs in comparison to PAFLCs

comparison to pulmonary arterial fibroblast-like cells. These results suggest that not only TGF- $\beta 1$ nor Ras, but also additional factors, may be essential for this transitional pathway. Indeed, TGF- $\beta 1$ is currently thought to be insufficient to induce the late stage of SM differentiation in non-SMC lineage cells [24]. Moreover, neither
TGF- $\beta 1$ nor activated Ras alone were capable of inducing $\alpha$-SMA expression [28].

The effects of conditioned media may be particularly remarkable if chemically defined culture media without serum additions is employed. Therefore, serum free media was adapted for the conditioned media 
Table 3 Endothelial Cell Biology PCR Array

\begin{tabular}{|c|c|c|c|c|}
\hline Biological process description & Gene name & $\begin{array}{c}\text { Gene } \\
\text { symbol }\end{array}$ & Public ID & P-value \\
\hline $\begin{array}{l}\text { Permissibility and Vessel Tone: } \\
\text { Angiotensin System }\end{array}$ & Angiotensin II receptor, type 1 & AGTR1 & NM_031850 & 0.030612 \\
\hline $\begin{array}{l}\text { Endothelial Cell Injury: } \\
\text { Caspase Activation }\end{array}$ & $\begin{array}{c}\text { Caspase 1, apoptosis-related cysteine peptidase (interleukin 1, beta, } \\
\text { convertase) }\end{array}$ & CASP1 & NM_033292 & 0.005519 \\
\hline $\begin{array}{c}\text { Endothelial Cell Activation: } \\
\text { Other Genes Involved in Cell } \\
\text { Growth }\end{array}$ & TIMP metallopeptidase inhibitor 1 & TIMP1 & NM_003254 & 0.049858 \\
\hline
\end{tabular}

Functional classification of highly expressed genes in co-cultured HPMVECs with MFLCs in comparison to PAFLCs

experiments. However, this leads to serum starvation on the cells, which commonly leads to cell cycle arrest and induces changes in protein synthesis. Accordingly, coculture experiments were conducted in media with serum, which allows different cell types to grow on either side of the membrane and may be able to detect the mutual effects of cell types on one another.

An inactivation of autophagy was found in both ELCs (Figure 2K) and human pulmonary microvascular ECs co-cultured with MFLCs (Figure 6B) compared to the expression in human pulmonary microvascular ECs cocultured with pulmonary arterial fibroblast-like cells (Figure 6A), thus suggesting that in these cells, protein synthesis predominates over protein degradation. Moreover, the decreased expression of cell death-related genes indicated that cell growth may be stimulated (Figure 5A). This inactivation could benefit cancer cells. Recently several genetic links between autophagy defects and cancers have been shown, providing increasing support for the concept that autophagy is a genuine tumor suppressor pathway [29]. Signaling pathways that regulate autophagy overlaps with those that regulate tumorigenesis [16].

This study has shown that human pulmonary microvascular ECs co-cultured with MFLCs and ELCs have fewer mitochondria with an organized reticulum (Figure $6 \mathrm{E}, 2 \mathrm{H}$ ) and SOD-2, which is an enzyme found only in the mitochondria, is decreased in these cells (Figure $6 \mathrm{H}$, 2L). Endothelial cell biology PCR array demonstrated the decreased expression of SOD1 (Table 2), which is located in the cytoplasm. Both SOD1 and 2 are an important antioxidant defense in almost all cells exposed to oxygen. Moreover, the decreased production of ROS has been detected in ECs co-cultured with MFLCs in comparison to the expression in those co-cultured with pulmonary arterial fibroblast-like cells (Figure 5D). These results including fewer mitochondria, the decreased expression of SOD, and normoxic decreases in ROS are compatible with the characteristics of mitochondrial abnormalities in $\mathrm{PAH}$, demonstrated by Archer et al [25]. The metabolic shift from oxidative mitochondrial metabolism to the glycolytic metabolism inhibits acetyl-CoA to enter the Krebs' Cycle, resulting in reduced production of ROS. However, gene and protein expression of SOD are not directly translated into activity and the decreased production of ROS is not sufficient to determine SOD activity. It has been shown that pulmonary artery SMCs in PAH are associated with mitochondrial disorders [30-32]. Xu and colleagues used an in vitro experiment with pulmonary artery ECs from idiopathic PAH (IPAH ECs) and control lungs (control ECs) to show that glucose metabolism plays the primary role in the energy requirements of IPAH ECs, based on the 3-fold greater glycolytic rate of IPAH ECs compared with control ECs. This indicates that there is mitochondrial dysfunction in ECs in patients with idiopathic $\mathrm{PAH}$, similar to the SMCs in PAH [33]. The existence of mitochondrial disorder/dysfunction in commercially available pulmonary microvascular ECs co-cultured with MFLCs in CTEPH and ECs in PAH, may support the similarities in the microvascular remodeling in the two disease.

Although several protein kinases regulate autophagy, the mammalian target of rapamycin (mTOR), which negatively regulates the pathway in organisms from yeast to man, is the best characterized [15]. Rapamycin is an inhibitor of mTOR and an anti-proliferative immunosuppressor that arrests cells in the G1 phase of the cell cycle [34]. Rapamycin is used clinically in cardiovascular medicine as an anti-proliferative agent applied to coronary stents to reduce local restenosis [35]. Rapamycin inhibits hypoxia-induced activation of S6 kinase in pulmonary arterial adventitial fibroblasts [36], suggesting the possibility that there may be a therapeutic benefit in PAH. Moreover, rapamycin has an anti-proliferative effect on pulmonary arterial SMCs derived from endarterectomized tissues of CTEPH patients [37]. In this study, we demonstrated that rapamycin reversed the decrease in autophagy in the ECs co-cultured with MFLCs (Figure 5A, 6C). Moreover, rapamycin also reversed the disruption of the mitochondrial reticulum and restored the localization of SOD-2 (Figure 6F, I). It is acknowledged that mTOR activity antagonize induction of the general stress response genes including 
SOD-2 gene [38-40]. This may explain the mechanisms by which rapamycin exerts its beneficial changes on cellular mitochondria and SOD2 expression. Indeed, SOD2 is located within the mitochondrial matrix and was strongly induced in response to rapamycin in normal and neoplastic mammalian cells [41]. It also reversed the change in expression of 11 of the 15 genes decreased by co-culture and the 3 genes increased by co-culture that were related to endothelial cell biology (Figure 5B) (Table 2, 3), thus suggesting that rapamycin (as an anti-proliferative agent) has beneficial therapeutic effects, not only on pulmonary arterial SMCs, but also on pulmonary arterial ECs which exist in the close contact with MFLCs, in the patients with CTEPH. However, because rapamycin may act on the proliferation rate of MFLCs more than pulmonary arterial fibroblast-like cells [37], it is possible that this action may be an alternative explanation for the observed differences. Moreover, a few transitional cells were observed in the ECs co-culture with MFLCs that were treated with rapamycin (data not shown), indicating that rapamycin might exert no beneficial effect on EnMT.

\section{Conclusions}

Our experiments with ECs and MFLCs demonstrated that factors associated with MFLCs in the microenvironment created by the unresolved clot might induce EC dysfunction through EnMT (3F, 3G, 4D, 4E),

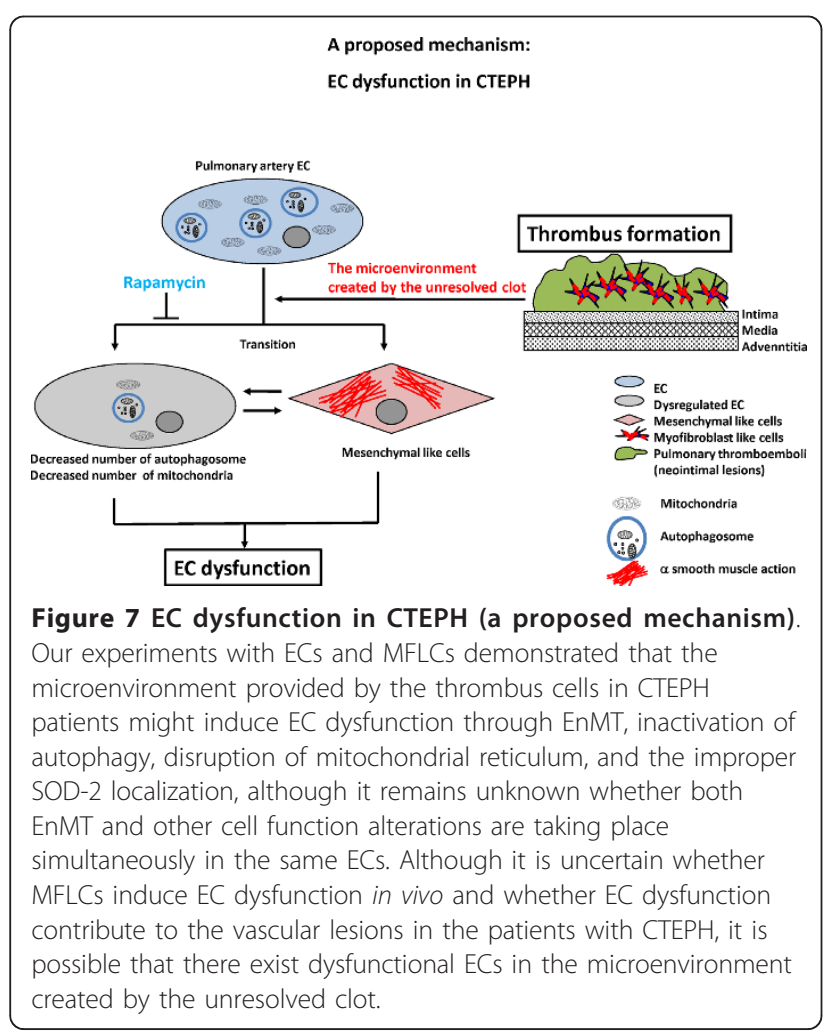

inactivation of autophagy (Figure 5A, 6B), disruption of the mitochondrial reticulum, and improper localization of SOD-2 (Figure 6E, H). Indeed, ELCs, which were isolated from the PEA tissues of CTEPH patients, included a few transitional cells (coexpressing both endothelialand SM- cell markers) (Figure 2J), lost their ability to form autophagosomes (Figure $2 \mathrm{~K}$ ) and had defective mitochondrial structure/function (Figure 2L). Although it is uncertain whether MFLCs induce EC dysfunction in vivo and whether EC dysfunction contribute to the vascular lesions in the patients with CTEPH, it is possible that there exist dysfunctional ECs in the microenvironment created by the unresolved clot (Figure 7). However, non-resolving pulmonary thromboemboli in CTEPH mainly consist of fibrotic tissue representing the end-stage of a thrombus organization process. Therefore, it remains uncertain whether any of the cellular or molecular findings at this stage of disease are causally involved in disease pathogenesis. We should acknowledge the purely descriptive nature of this study that does not confer any pathophysiological evidence in CTEPH.

\section{Acknowledgements}

All authors read and approved the final manuscript. We thank Dr. J. T. Reeves, who enriched our research for many years.

All sources of support

This study was supported by Research Grants for the Respiratory Failure Research Group, the Cardiovascular Diseases (19-9), and Research on Intractable Diseases (22-33) from the Ministry of Health, Labor and Welfare, Japan, and a Grant-in-Aid for Scientific Research (Category C 22590851) from the Japanese Ministry of Education and Science.

\section{Author details}

'Department of Respirology (B2), Graduate School of Medicine, Chiba University, 1-8-1 Inohana, Chuo-ku, Chiba 260-8670, Japan. ${ }^{2}$ Department of Surgical Pathology, Hyogo College of Medicine, 1-1 Mukogawa-cho, Nishinomiya, Hyogo, 663-8501, Japan.

\section{Authors' contributions}

SS conceived of the report, contributed to its design and conception, drafted the manuscript and carried out the all studies. $\mathrm{HH}$ carried out the pathological studies. NT drafted the manuscript and contributed to its design and conception. YK contributed to its design. KK carried out the pathological studies. $K T$ contributed to its design and drafted the manuscript. All authors read and approved the final manuscript.

\section{Competing interests}

Dr. Tatsumi has received honoraria for lectures from Glaxo Smith Kline, Actelion Pharmaceutical Ltd. Dr. Tanabe has received honoraria for lectures from Actelion, Glaxo Smith Kline, Astellas and Pfizer and research grant support from Actelion Pharmaceutical Ltd. The other authors report no conflicts.

Received: 23 May 2011 Accepted: 22 August 2011

Published: 22 August 2011

\section{References}

1. Klepetko W, Mayer E, Sandoval J, Trulock EP, Vachiery JL, Dartevelle P, Pepke-Zaba J, Jamieson SW, Lang I, Corris P: Interventional and surgical modalities of treatment for pulmonary arterial hypertension. J Am Coll Cardiol 2004, 43(suppl S):73S-80S. 
2. Jamieson SW, Kapelanski DP, Sakakibara N, Manecke GR, Thistlethwaite PA, Kerr KM, Channick RN, Fedullo PF, Auger WR: Pulmonary endarterectomy: experience and lessons learned in 1,500 cases. Ann Thorac Surg 2003, 76:1457-1462; discussion 1462-1454

3. Fanikos J, Piazza G, Zayaruzny M, Goldhaber SZ: Long-term complications of medical patients with hospital-acquired venous thromboembolism. Thromb Haemost 2009, 102:688-693.

4. Cohen AT, Agnelli G, Anderson FA, Arcelus JI, Bergqvist D, Brecht JG, Greer IA, Heit JA, Hutchinson JL, Kakkar AK, Mottier D, Oger E, Samama MM, Spannagl M: VTE Impact Assessment Group in Europe (VITAE). Venous thromboembolism (VTE) in Europe. The number of VTE events and associated morbidity and mortality. Thromb Haemost 2007, 98:756-764.

5. Hoeper MM, Mayer E, Simonneau G, Rubin L: Chronic thromboembolic pulmonary hypertension. Circulation 2006, 113:2011-2020.

6. Moser KM, Bloor CM: Pulmonary vascular lesions occurring in patients with chronic major vessel thromboembolic pulmonary hypertension. Chest 1993, 103:685-692.

7. Azarian $R$, Wartski M, Collignon MA, Parent F, Herve $P$, Sors $H$, Simonneau G: Lung perfusion scans and hemodynamics in acute and chronic pulmonary embolism. J NuCl Med 1997, 38:980-983.

8. Yi ES, Kim H, Ahn H, Strother J, Morris T, Masliah E, Hansen LA, Park K, Friedman PJ: Distribution of obstructive intimal lesions and their cellular phenotypes in chronic pulmonary hypertension: a morphometric and immunohistochemical study. Am J Respir Crit Care Med 2000, 162:1577-1586.

9. Sakao S, Taraseviciene-Stewart L, Lee JD, Wood K, Cool CD, Voelkel NF: Initial apoptosis is followed by increased proliferation of apoptosisresistant endothelial cells. FASEB J 2005, 19:1178-1180.

10. Masri FA, Xu W, Comhair SA, Asosingh K, Koo M, Vasanji A, Drazba J, Anand-Apte B, Erzurum SC: Hyperproliferative apoptosis-resistant endothelial cells in idiopathic pulmonary arterial hypertension. Am J Physiol Lung Cell Mol Physiol 2007, 293:L548-L554.

11. Firth AL, Yao W, Ogawa A, Madani MM, Lin GY, Yuan JX: Multipotent mesenchymal progenitor cells are present in endarterectomized tissues from patients with chronic thromboembolic pulmonary hypertension. Am J Physiol Cell Physiol 2010, 298:C1217-C1225.

12. Maruoka M, Sakao S, Kantake M, Tanabe N, Kasahara Y, Kurosu K, Takiguchi Y, Masuda M, Yoshino I, Voelkel NF, Tatsumi K: Characterization of myofibroblasts in chronic thromboembolic pulmonary hypertension. Int J Cardiol 2011.

13. Sakao S, Taraseviciene-Stewart L, Cool CD, Tada Y, Kasahara Y, Kurosu K, Tanabe N, Takiguchi Y, Tatsumi K, Kuriyama T, Voelkel NF: VEGF-R blockade causes endothelial cell apoptosis, expansion of surviving CD34+ precursor cells and transdifferentiation to smooth muscle-like and neuronal-like cells. FASEB J 2007, 21:3640-3652.

14. Sahara M, Sata M, Morita T, Nakamura K, Hirata Y, Nagai R: Diverse contribution of bone marrow-derived cells to vascular remodeling associated with pulmonary arterial hypertension and arterial neointimal formation. Circulation 2007, 115:509-517.

15. Klionsky DJ, Emr SD: Autophagy as a regulated pathway of cellular degradation. Science 2000, 290:1717-1721.

16. Levine B, Kroemer G: Autophagy in the pathogenesis of disease. Cell 2008, 132:27-42.

17. Lindahl P, Johansson BR, Levéen P, Betsholtz C: Pericyte loss and microaneurysm formation in PDGF-B-deficient mice. Science 1997, 277:242-245

18. Hirschi K, Rohovsky SA, D'Amore PA: PDGF, TGF- $\beta$ and heterotypic cell-cell interactions mediate the recruitment and differentiation of $10 \mathrm{~T} 1 / 2$ cells to a smooth muscle cell fate. J Cell Biol 1998, 141:805-814.

19. Hellström M, Kalén M, Lindahl P, Abramsson A, Betsholtz C: Role of PDGF-B and PDGFR- $\beta$ in recruitment of vascular smooth muscle cells and pericytes during embryonic blood vessel formation in the mouse. Development 1999, 126:3047-3055.

20. Allanach K, Mengel M, Einecke G, Sis B, Hidalgo LG, Mueller T, Halloran PF: Comparing microarray versus RT-PCR assessment of renal allograft biopsies: similar performance despite different dynamic ranges. Am J Transplant 2008, 8:1006-1015.

21. Wang Y, Barbacioru C, Hyland F, Xiao W, Hunkapiller KL, Blake J, Chan F, Gonzalez C, Zhang L, Samaha RR: Large scale real-time PCR validation on gene expression measurements from two commercial longoligonucleotide microarrays. BMC Genomics 2006, 7:59.
22. Frid MG, Kale VA, Stenmark KR: Mature vascular endothelium can give rise to smooth muscle cells via endothelial-mesenchymal transdifferentiation: in vitro analysis. Circ Res 2002, 14:1189-1196.

23. Arciniegas $E$, Sutton AB, Allen TD, Schor AM: Transforming growth factor beta 1 promotes the differentiation of endothelial cells into smooth muscle-like cells in vitro. J Cell Sci 1992, 103:521-529.

24. Hautmann MB, Adam PJ, Owens GK: Similarities and differences in smooth muscle a-actin induction by TGF-s in smooth muscle versus non-smooth muscle cells. Arterioscler Thromb Vasc Biol 1999, 19:2049-2058.

25. Archer SL, Gomberg-Maitland M, Maitland ML, Rich S, Garcia JG, Weir EK: Mitochondrial metabolism, redox signaling, and fusion: a mitochondriaROS-HIF-1alpha-Kv1.5 O2-sensing pathway at the intersection of pulmonary hypertension and cancer. Am J Physiol Heart Circ Physiol 2008, 294:570-578

26. Arciniegas E, Frid MG, Douglas IS, Stenmark KR: Perspectives on endothelial-to-mesenchymal transition: potential contribution to vascular remodeling in chronic pulmonary hypertension. Am J Physiol Lung Cell Mol Physiol 2007, 293:L1-8.

27. Yao W, Firth AL, Sacks RS, Ogawa A, Auger WR, Fedullo PF, Madani MM, Lin GY, Sakakibara N, Thistlethwaite PA, Jamieson SW, Rubin LJ, Yuan JX: Identification of putative endothelial progenitor cells (CD34+CD133+Flk$1+$ ) in endarterectomized tissue of patients with chronic thromboembolic pulmonary hypertension. Am J Physiol Lung Cell Mol Physiol 2009, 296:L870-878.

28. Hashimoto N, Phan SH, Imaizumi K, Matsuo M, Nakashima H, Kawabe T, Shimokata K, Hasegawa Y: Endothelial-mesenchymal transition in bleomycin-induced pulmonary fibrosis. Am J Respir Cell Mol Biol 2010, 43:161-172.

29. Levine B: Cell biology: autophagy and cancer. Nature 2007, 446:745-747.

30. Bonnet S, Archer SL, Allaluis-Turner J, Haromy A, Beaulieu C, Thompson R, Lee CT, Lopaschuk GD, Puttagunta L, Bonnet S, Harry G, Hashimoto K, Porter CJ, Andrade MA, Thebaud B, Michelakis ED: A mitochondria-K channel axis is suppressed in cancer and its normalization promotes apoptosis and inhibits cancer growth. Cancer Cell 2003, 11:37-51.

31. Bonnet S, Michelakis ED, Porter CJ, Andrade-Navarro MA, Thébaud B, Bonnet S, Haromy A, Harry G, Moudgil R, McMurtry MS, Weir EK, Archer SL: An abnormal mitochondrial-HIF-1-Kv channel pathway disrupts oxygensensing and triggers pulmonary arterial hypertension (PAH) in fawnhooded rats: similarities to human PAH. Circulation 2006, 113:2630-2641.

32. Bonnet S, Rochefort G, Sutendra G, Archer SL, Haromy A, Webster L, Hashimoto K, Bonnet SN, Michelakis ED: The nuclear factor of activated T cells in pulmonary arterial hypertension can be therapeutically targeted. Proc Natl Acad Sci USA 2007, 104:11418-11423.

33. Xu W, Koeck T, Lara AR, Neumann D, DiFilippo FP, Koo M, Janocha AJ, Masri FA, Arroliga AC, Jennings C, Dweik RA, Tuder RM, Stuehr DJ, Erzurum SC: Alterations of cellular bioenergetics in pulmonary artery endothelial cells. Proc Natl Acad Sci USA 2007, 104:1342-1347.

34. Brown EJ, Albers MW, Shin TB, Ichikawa K, Keith CT, Lane WS, Schreiber SL: A mammalian protein targeted by G1-arresting rapamycinreceptor complex. Nature 1994, 369:756-758.

35. Morice MC, Serruys PW, Sousa JE, Fajadet J, Ban Hayashi E, Perin M, Colombo A, Schuler G, Barragan P, Guagliumi G, Molnàr F, Falotico R, RAVEL Study Group. RAVEL Study Group: A randomized comparison of a sirolimus-eluting stent with a standard stent for coronary revascularization. N Engl J Med 2002, 346:1773-1780.

36. Gerasimovskaya EV, Tucker DA, Stenmark KR: Activation of phosphatidylinositol 3-kinase, Akt, and mammalian target of rapamycin is necessary for hypoxia-induced pulmonary artery adventitial fibroblast proliferation. J Appl Physiol 2005, 98:722-731.

37. Ogawa A, Firth AL, Yao W, Madani MM, Kerr KM, Auger WR, Jamieson SW, Thistlethwaite PA, Yuan JX: Inhibition of mTOR attenuates store-operated $\mathrm{Ca} 2+$ entry in cells from endarterectomized tissues of patients with chronic thromboembolic pulmonary hypertension. Am J Physiol Lung Cell Mol Physiol 2009, 297:L666-676.

38. Beck T, Hall MN: The TOR signalling pathway controls nuclear localization of nutrient-regulated transcription factors. Nature 1999, 402:689-692.

39. Görner W, Durchschlag E, Martinez-Pastor MT, Estruch F, Ammerer G, Hamilton B, Ruis $\mathrm{H}$, Schüller C: Nuclear localization of the $\mathrm{C} 2 \mathrm{H} 2$ zinc finger protein Msn2p is regulated by stress and protein kinase $A$ activity. Genes Dev 1998, 12:586-597. 
40. Görner W, Durchschlag E, Wolf J, Brown EL, Ammerer G, Ruis H, Schüller C: Acute glucose starvation activates the nuclear localization signal of a stress-specific yeast transcription factor. EMBO J 2002, 21:135-144.

41. Zurita-Martinez SA, Cardenas ME: Tor and cyclic AMP-protein kinase A: two parallel pathways regulating expression of genes required for cell growth. Eukaryot Cell 2005, 4:63-71.

doi:10.1186/1465-9921-12-109

Cite this article as: Sakao et al:: Endothelial-like cells in chronic

thromboembolic pulmonary hypertension: crosstalk with myofibroblast-

like cells. Respiratory Research 2011 12:109.

Submit your next manuscript to BioMed Central and take full advantage of:

- Convenient online submission

- Thorough peer review

- No space constraints or color figure charges

- Immediate publication on acceptance

- Inclusion in PubMed, CAS, Scopus and Google Scholar

- Research which is freely available for redistribution

Submit your manuscript at www.biomedcentral.com/submit
() Biomed Central 